\title{
Iraqi looters spark alert over radiation risks
}

Geoff Brumfiel

Widespread looting in Iraq has raised fears about the fate of some 1,100 radioactive sources at sites across the country.

The sources, which were used in hospitals and industrial facilities, were catalogued by the International Atomic Energy Agency (IAEA) in the mid-1990s, but their fate in the weeks since the war ended is uncertain.

"There are some large and dangerous sources among them," says Melissa Flemming, a spokeswoman for the IAEA in Vienna. "We are deeply concerned about the possibility that some of this material has been broken into."

At Iraq's largest nuclear facility, the Tuwaitha Nuclear Research Centre near Baghdad, civilians have emptied containers of concentrated uranium oxide and used the metal drums to store food and water. The theft has been followed by reports of illness, but many scientists question whether uranium is the cause. Most of the metal was only slightly radioactive and would not have induced immediate radiation sickness in those handling it, says Michael Levi, a physicist at the Brookings Institution in Washington. Civilians would also have to ingest large amounts to feel the toxic effects of the heavy metal, he adds.

But uranium was not the only source of radiation at Tuwaitha. A 1993 IAEA inspection listed a partial inventory of 177 sources stored there, including 52 sources of cobalt-60 and 32 sources of caesium-137, as well as stores of other potentially dangerous isotopes such as iridium-192, strontium-90 and radium-226. Some of those sources are "very powerful" and pose a threat to anyone who might come across them, says David Albright, a former nuclear inspector

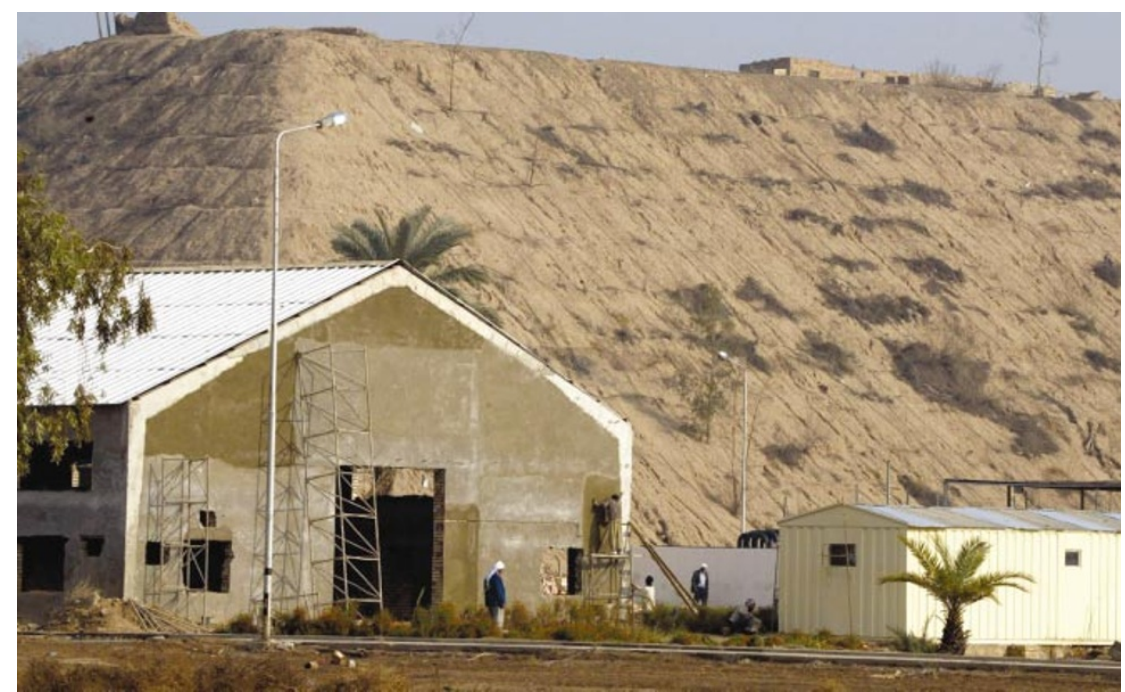

Safe and sound? Iraq's Tuwaitha Nuclear Research Centre holds a range of highly dangerous materials.

who has visited Tuwaitha and who now directs the Institute for Science and International Security in Washington. "My understanding is that some of them could be fatal," he says.

According to Flemming, 950 similar sources of varying size and power are scattered throughout the country. They were used in applications such as radiotherapy, X-rays, welding and oil surveying, she says. Such loose sources are dangerous because they can be mistaken for scrap metal and spread throughout the community. The most notorious incident occurred in 1987 in Goiânia, Brazil, when more than 200 people, several of whom later died, were exposed to a caesium-137 source scavenged from an abandoned hospital.

Because of their potential toxicity, these sources could also be valuable material for terrorists, says Joseph Cirincione, head of the nonproliferation project at the Carnegie Endowment for International Peace in Washington. "I'm less worried about the uranium that seems to have disappeared than the highly radioactive elements that would be perfect for enhancing an al-Qaeda truck bomb," he says. So far, there is no evidence that any material has found its way into the hands of terrorists.

The looting has increased the pressure on the United States to allow IAEA inspectors back into the country. The US army has deployed its nuclear-disablement team to assess Iraq's nuclear holdings, but Albright and others believe that the true condition of Iraq's nuclear sources will not be learned until the IAEA resumes inspections. "The United States is not on top of this," he says.

\section{Animal studies hint at staying power of SARS}

\section{Helen Pearson, New York}

Studies of viruses that infect farmyard and domestic animals indicate just how difficult severe acute respiratory syndrome (SARS) will be to tackle, scientists at a New York Academy of Sciences meeting heard last weekend.

Coronaviruses from the same family as that believed to cause SARS can trigger a variety of comparable lung and gut diseases in animals from chickens to cats. Factors that worsen animal infections might suggest why some SARS patients become highly infectious 'super-spreaders' or succumb more easily to the disease, delegates were told.

One tentative theory - that human patients infected with another virus or bacterium develop more severe symptoms when they catch SARS - was backed up by Linda Saif, a coronavirus expert at Ohio State University in Wooster. In unpublished work, Saif has shown that pigs carrying a lung infection before being inoculated with porcine respiratory coronavirus suffer a worse fever and longer infection than previously healthy swine.

Some SARS patients have been found to carry a common respiratory virus called human metapneumovirus. Donald Low, a microbiologist at Mount Sinai Hospital in Toronto, agreed that co-infection with this or another pathogen might exacerbate SARS symptoms, but researchers say that there are too little data on SARS to know whether
Saif's work is relevant to humans.

Researchers also discussed the probability that patients who are no longer showing symptoms of SARS could continue to spread the disease. Some national health authorities currently release patients from isolation once their symptoms disappear. But Kathryn Holmes, who studies coronaviruses at the University of Colorado Health Sciences Center in Denver, pointed out that cats infected with a coronavirus can continue to shed the virus for up to seven months after symptoms clear up (A. A. Herrewegh et al. Virology 234, 349-363; 1997).

Saif also discussed research that adds weight to concerns that the steroids commonly used to treat SARS in Hong Kong 


\section{Lack of trust hampers hunt for weapons}

\section{Declan Butler}

Confusion over how the US-led occupying powers will treat Iraqi scientists is hindering the search for weapons of mass destruction in the country, according to a growing number of weapons experts. Until the uncertainty ends, say observers, scientists who could hand over valuable information may be tempted to hide or flee to rogue nations.

The arrest of prominent Iraqi scientists, such as Huda Salih Mahdi Ammash, suspected of developing biological weapons, and Rihab Taha, a senior figure in the country's germwarfare programme, have recently made the headlines. Yet evidence of Iraq's alleged programmes for biological, chemical or nuclear weapons remains elusive, and some observers suggest that the coalition's treatment of Iraqi scientists may be partly to blame.

US radio broadcasts in Iraq have asked scientists to step forward, promising that they "will be treated with respect and dignity". But David Albright, president of the Washingtonbased Institute for Science and International Security and a former nuclear-weapons inspector in Iraq, says that he is in daily contact with Iraqi scientists who fear being taken prisoner by US forces, retaliation by Saddam loyalists, or kidnap and ransom to coalition authorities. Albright believes that all three are happening.

Concern that they may be treated as criminals removes scientists' incentive to cooperate, says Ibrahim al-Marashi, a research associate at the Center for Nonproliferation Studies in Monterey, California. Even those in custody are unlikely to cooperate until they receive assurances that they will not be prosecuted for war crimes, adds Jonathan Tucker, a weapons expert at the US Institute of Peace in Washington.

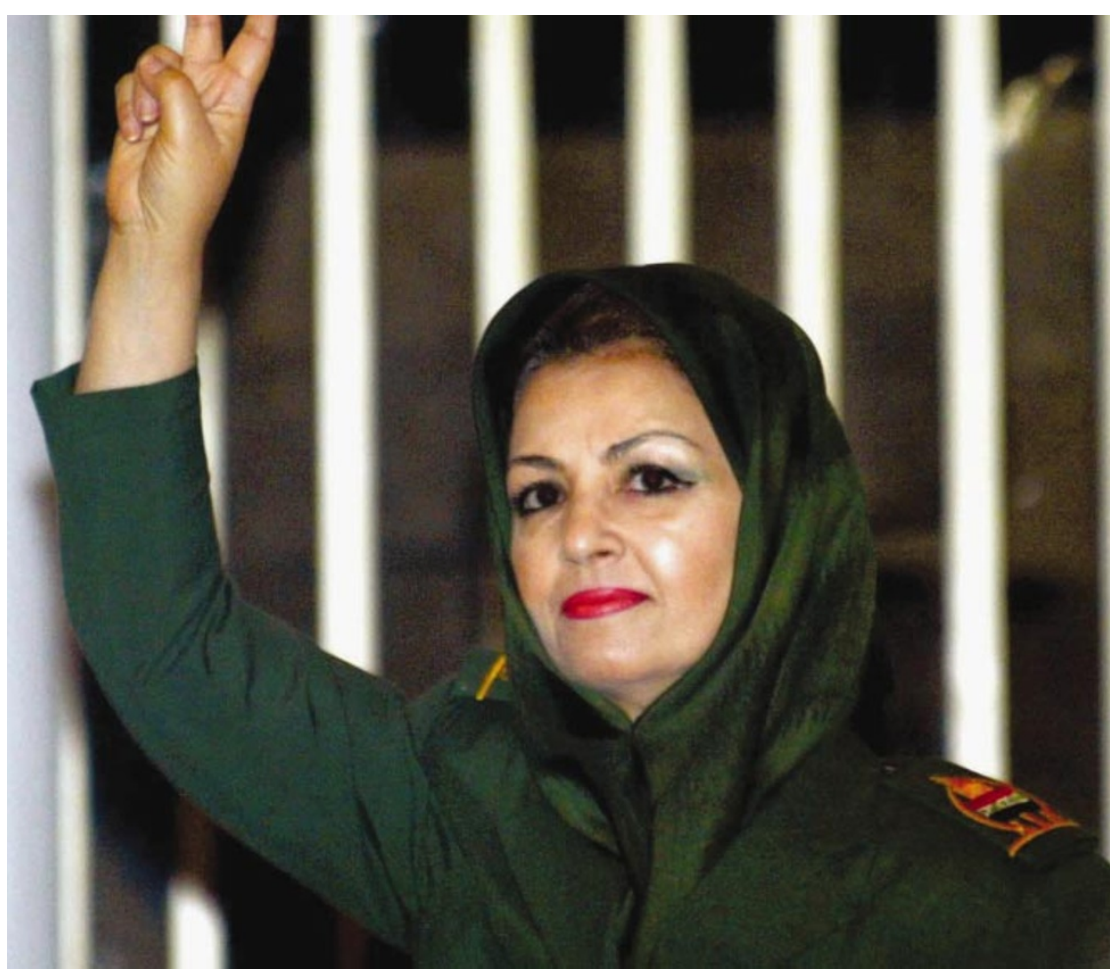

Huda Salih Mahdi Ammash is under arrest, but should rank-and-file Iraqi scientists face the same fate?

Officials at the United Nations Monitoring, Verification and Inspection Commission (UNMOVIC), which the United States has not yet allowed back into Iraq, say that the cooperation of Iraqi scientists is crucial. Without their help, say commission staff, it will difficult to gain an overview of what weapons Iraq might have produced, and in what quantity.

Others experts add that Iraqi scientists will be able to shed light on crucial issues, such as might instead be exacerbating the disease (see Nature 423, 4; 2003). She warned that dexamethasone, an anti-inflammatory corticosteroid, can actually worsen a coronavirus infection in cows and prolong the period of time for which they release virus (H. Tsunemitsu, D. R. Smith and L. J. Saif Arch. Virol. 144, 167-175; 1999).

Saif also cautioned that researchers have had limited success in producing vaccines against animal coronaviruses. Several studies have shown that experimental vaccines against feline infectious peritonitis virus (FIPV), for example, can aggravate the infection through a phenomenon called antibody-dependent enhancement. Antibodies produced in response to vaccination with FIPV proteins bind to the virus and boost its uptake by immune cells called macrophages. Other viruses are destroyed when engulfed by macrophages, but in this case the FIPV multiplies inside the cells.

This suggests that one possible strategy to fight SARS - collecting and injecting antibodies from recovering patients into new patients - might similarly inflame the disease. Pharmaceutical-industry representatives at the meeting reiterated that the hope of a quick drug or vaccine for SARS is slim. A new antiviral drug would take a minimum of four to five years to reach the shelf, they said, a vaccine closer to six.

www.nyas.columbia.edu the fate of Iraq's dual-use materials - substances that could be used to create weapons but which could also have peaceful applications. And some observers note that, in the past, weapons programmes have remained hidden until being revealed by scientists.

Tucker argues that weapons scientists who were not key figures in Saddam's regime should be given an amnesty and incentives to cooperate, to discourage them from fleeing or selling their talents elsewhere. He recommends that a centre be set up in Baghdad to offer weapons scientists stable employment, along the lines of the International Science and Technology Center in Moscow, an intergovernmental organization established in 1992 to divert the talents of Soviet weapons scientists to peaceful ends.

But others question how much information Iraqi scientists will be able to supply. "Very few people were probably in the know - only those closest to Saddam or the 'simpletons' who did the actual concealment work," says Ephraim Asculai of the Jaffee Center for Strategic Studies at Tel Aviv University in Israel.

The current coalition weapons inspectors are due to be replaced in the coming weeks by the Iraq Survey Group, a 2,000-strong Pentagon-led body that will investigate everything from weapons and potential war crimes to terrorist connections. The coalition has not yet responded to requests to allow inspectors from UNMOVIC or the International Atomic Energy Agency to return to Iraq. 